\title{
Changing Methodologies in TESOL
}

Jane Spiro 
(C) the chapter their several authors, 2013

Edinburgh University Press Ltd

22 George Square, Edinburgh EH8 9LF

www.euppublishing.com

Typeset in 10/12 Minionby Servis Filmsetting Ltd, Stockport, Cheshire, and printed and bound in Great Britain by CPI Group (UK) Ltd, Croydon CR0 4YY

A CIP record for this book is available from the British Library

ISBN 9780748646203 (hardback)

ISBN 9780748646197 (paperback)

ISBN 9780748677627 (webready PDF)

ISBN 9780748677641 (epub)

The right of the contributors

to be identified as author of this work

has been asserted in accordance with

the Copyright, Designs and Patents Act 1988. 